- COMMENTARY

Volume 9 Issue 42017

DOI: 10.21315/eimj2017.9.4.8

ARTICLE INFO

Submitted: 7-10-2017

Accepted: 16-11-2017

Online: 29-12-2017

\section{Challenges with Regard to Undergraduate Medical Education in Offshore Caribbean Medical Schools}

\author{
P. Ravi Shankar, Ramanan Balasubramanium, Gabriel Dakubo \\ American International Medical University, Gros Islet, SAINT \\ LUCIA
}

To cite this article: Shankar PR, Balasubramanium R, Dakubo G. Challenges with regard to undergraduate medical education in offshore Caribbean medical schools. Education in Medicine Journal. 2017;9(4):69-75. https://doi.org/10.21315/eimj2017.9.4.8

To link to this article: https://doi.org/10.21315/eimj2017.9.4.8

\title{
ABSTRACT
}

The article examines challenges facing undergraduate medical education at offshore Caribbean medical schools (OMS) with reference to the literature and the authors' personal experiences. While some of the challenges have been highlighted in the literature, a comprehensive overview of this important issue is lacking. The authors searched the PubMed and the Google Scholar database using the search terms 'Caribbean medical schools' and 'offshore medical schools'. The articles retrieved were critically examined by the authors. The selected articles were used in writing the manuscript. Among the challenges identified were geographical and social isolation, decreased opportunities for faculty development, less emphasis on practical skills and small group learning, greater emphasis on didactic lectures, social accountability and community-based learning, less emphasis on research and publication, problems with clinical teaching facilities, changing accreditation requirements, and climate change. Possible solutions and lessons for educators elsewhere are also mentioned. These challenges require innovative solutions.

Keywords: Caribbean, Challenges, Medical schools, Teaching-learning, Undergraduate

CORRESPONDING AUTHOR

P. Ravi Shankar, American International Medical University, No. 1, AIM-U Avenue, Beausejour Road, Gros Islet, Saint Lucia, LC01 101 | Email: ravi.dr.shankar@gmail.com

\section{INTRODUCTION}

Offshore medical schools (OMS) in the Caribbean have traditionally focused on educating American or Canadian citizens to return home to practice medicine. Recently there is a focus on students from India, other South Asian countries and West Africa (principally Nigeria and Ghana). A recent article mentions that OMS may be best regarded as 'hybrid medical schools' where students complete their basic sciences in the Caribbean and then do their clinical rotations mainly in the United States (US) (1).
Having worked in and been involved with quality assurance activities in different medical schools both within and outside the Caribbean for many years, the authors identify a number of challenges with regard to OMS based on their personal experiences. They also searched the PubMed and the Google Scholar database using the search terms 'Caribbean medical schools' and 'offshore medical schools'. The articles retrieved were critically examined by the authors to determine their relevance to the topic and were used in writing the manuscript. 


\section{WHAT THIS PAPER ADDS TO THE CURRENT UNDERSTANDING OF THE SUBJECT}

While some manuscripts have examined some of the challenges facing OMS these have been written mainly from a US perspective and a critical viewpoint. Perspective from educators working in OMS and possible suggestions to address these challenges are lacking. In the manuscript the authors try to provide this 'missing' perspective.

\section{Quality of Education}

Concerns have been expressed about the quality of education offered at $\operatorname{OMS}(2,3)$. Most OMS have three student intakes a year and either less stringent Medical College Admission Test (MCAT) score requirements or do not require MCAT as part of the admission process. A concern is whether the shorter duration of basic science education (20 months at most schools) provides an adequate scientific foundation for medical practice. However, teachers and students at OMS have often mentioned that the education offered does adequately prepare students for passing the United States Medical Licensing Examinations (USMLE) and licensing exams and a medical career (3).

\section{Geographical and Social Isolation}

Most OMS are located on small Caribbean islands/countries with populations ranging from 1,500 to 400,000 . Compared to institutions elsewhere most schools have only one or two faculties for each discipline. Each school is its own university and hence there is little interaction between faculties working at different schools. The main objective of the preclinical course is to prepare students for the USMLE Step 1. Faculty members do not get an 'official' opportunity to visit other medical schools. Also most schools are 'for-profit' businesses hence free sharing of information is not always encouraged. However, OMS vary widely in their size, location and the teaching-learning methods employed (4).

\section{Decreased Opportunities for Development}

There are fewer opportunities for professional growth and development. As the number of faculty is less, faculty members are busy teaching during most of the working week. The quality of faculty development activities varies across schools. Accreditation requirements are pushing schools toward offering some degree of faculty development and training. Most islands and schools have acceptable access through the internet to a large number of learning resources. Webinars are becoming an important means of faculty development. Many faculty members are also enrolled in fellowships and Masters programs offered by the Foundation for Advancement of International Medical Education and Research (FAIMER) and other agencies. The regional accreditation agency, Caribbean Accreditation Authority for education in Medicine and other Health Professions (CAAM-HP) also periodically offers opportunities for faculty interaction and knowledge/skill development (5].

\section{Less Emphasis on Practical Skills and Small Group Learning}

Most steps of the USMLE primarily focus on didactic knowledge. The clinical skills portion of USMLE Step 2 was introduced following concerns about the clinical skills of graduates from OMS. The exam drives medical schools to adhere to a set of minimum standards for teaching patient-doctor communication skills (6). Accreditation agencies increasingly emphasise small group learning and 'practical' and laboratory sessions during the basic sciences and encourage OMS to strengthen these areas.

\section{Greater Emphasis on Didactic Lectures}

Most medical schools globally are decreasing the time and effort devoted to 
didactic lectures and encouraging more 'active' learning methods. As mentioned before, OMS are a diverse group but in general, lectures continue to be a dominant teaching-learning strategy according to the authors' personal observations. With increasing emphasis on accreditation, change may be slowly coming to OMS but educational innovation and use of newer teaching-learning methods are still not their 'strong points'. In many OMS over $80 \%$ to $90 \%$ of curricular time is still devoted to didactic lectures.

\section{Social Accountability and Community- based Learning}

Both social accountability and communitybased learning are challenges for OMS (7). The involvement of OMS in health systems of the Caribbean countries is often minimal though some schools are working to create these linkages. OMS regularly conduct community outreach/health camps with the objectives of improving clinical training of their students and health status of the community. Schools also utilise the health facilities on the islands and local health practitioners to provide clinical exposure to their students.

\section{Less Emphasis on Research and Publication}

Research has been given less emphasis in OMS. The authors observe that most OMS lack the laboratories to conduct medical research. Educational research is increasingly being prioritised as it does not require expensive resources and has the potential to improve teaching-learning. Student review articles are being used to create interest in research among students. The data obtained during various health camps is also analysed and published by many groups of students. Some schools offer students a research semester during which students can take a trimester leave of absence to conduct research in the United States and other countries.

\section{Problems with Clinical Teaching Facilities}

Most OMS do not own and operate clinical facilities. Traditionally students complete the basic sciences in the Caribbean and then do their clinical rotations in the US and Canada. Students studying at some of the older and larger OMS are eligible for US federal loans. A recent study mentions that students of only four OMS were eligible for federal loans (8). A concern has been raised that these larger schools pay large amounts to US hospitals to 'buy' clinical clerkships $(9,10)$. OMS offer clinical rotations at hospitals located in different countries. Some accreditation agencies require that students complete their clinical rotations in hospitals located in the same country or region where they completed their basic sciences. This creates further pressure on clinical training sites. Most hospitals train students from different medical schools. These practices create challenges in maintaining the quality and uniformity of clinical training. Increasing competition is limiting the number of clinical teaching sites available and a greater amount of resources is being required to fund clinical training (11).

\section{Changing Accreditation Requirements}

The US Educational Commission for Foreign Medical Graduates (ECFMG) requires that for registration after 2023, doctors must graduate from a medical school that has been properly accredited (12) through a formal process that uses criteria comparable to those used by the US Liaison Committee on Medical Education or uses globally accepted criteria like those put forward by the World Federation for Medical Education (WFME). The two main agencies that accredit schools in the Caribbean, CAAM-HP and the Accreditation Commission on Colleges of Medicine (ACCM) are recognised by WFME. Due to 'shortcomings' especially with regard to clinical teaching most medical schools have either been provisionally accredited or accredited with conditions by 
Table 1: Possible solutions to the challenges facing OMS

\begin{tabular}{|c|c|}
\hline Challenge & Possible solutions \\
\hline Geographical and social isolation & $\begin{array}{l}\text { Creating closer linkages between faculties at different OMS. Forming } \\
\text { an organisation for OMS faculty members. } \\
\text { Collaboration between faculty members for teaching-learning and } \\
\text { research. }\end{array}$ \\
\hline $\begin{array}{l}\text { Decreased opportunities for } \\
\text { development }\end{array}$ & $\begin{array}{l}\text { Utilising the resources of the previously mentioned faculty } \\
\text { organisation to promote faculty development. } \\
\text { Request the regional accrediting agencies to organise a greater } \\
\text { number of meetings and workshops. } \\
\text { Strengthening faculty development activities at individual OMS. }\end{array}$ \\
\hline $\begin{array}{l}\text { Less emphasis on practical skills } \\
\text { and small group learning }\end{array}$ & $\begin{array}{l}\text { Strengthen regional accreditation initiatives. } \\
\text { Create a requirement that each OMS has at least one medical } \\
\text { educator on its faculty. } \\
\text { Conducting faculty development workshops with regard to advances } \\
\text { in teaching-learning and assessment. }\end{array}$ \\
\hline $\begin{array}{l}\text { Greater emphasis on didactic } \\
\text { lectures }\end{array}$ & $\begin{array}{l}\text { Strengthen regional accreditation initiatives. } \\
\text { Create a requirement that each OMS has at least one medical } \\
\text { educator on its faculty. } \\
\text { Conducting faculty development workshops with regard to advances } \\
\text { in teaching-learning and assessment. }\end{array}$ \\
\hline $\begin{array}{l}\text { Social accountability and } \\
\text { community-based learning }\end{array}$ & $\begin{array}{l}\text { Accrediting agencies should determine how social accountability can } \\
\text { be applied to OMS. } \\
\text { OMS should work on creating linkages with local health systems. } \\
\text { Local health facilities can be utilised to provide clinical exposure to } \\
\text { students with the possibility of mutual benefit. } \\
\text { Provide greater community-based learning opportunities to basic } \\
\text { science students. } \\
\text { Appoint more faculty members with expertise in epidemiology and } \\
\text { public health. }\end{array}$ \\
\hline $\begin{array}{l}\text { Decreased emphasis on research } \\
\text { and publication }\end{array}$ & $\begin{array}{l}\text { Accreditation agencies should provide greater weight to research } \\
\text { and publications during the accreditation process. } \\
\text { Creating stronger linkages with local health systems and } \\
\text { organisations } \\
\text { Encourage collaborative research between faculty members of } \\
\text { different OMS. }\end{array}$ \\
\hline $\begin{array}{l}\text { Problems with clinical teaching } \\
\text { facilities }\end{array}$ & $\begin{array}{l}\text { Utilise local health facilities and hospitals for clinical teaching where } \\
\text { feasible. } \\
\text { OMS can operate a small clinical facility on the island and may be a } \\
\text { larger one in the US or Canada. }\end{array}$ \\
\hline $\begin{array}{l}\text { Changing accreditation } \\
\text { requirements }\end{array}$ & $\begin{array}{l}\text { All OMS should prepare themselves for accreditation by the regional } \\
\text { agencies. } \\
\text { Obtaining and maintaining accreditation will be a challenge for most } \\
\text { OMS. } \\
\text { Careful attention to ensuring financial stability and growth. }\end{array}$ \\
\hline Climate change & $\begin{array}{l}\text { OMS can educate students about climate change and train them to } \\
\text { play an important advocacy role. } \\
\text { Pressurise governments to play a more active role to reduce the } \\
\text { harmful effects of climate change. }\end{array}$ \\
\hline
\end{tabular}


CAAM-HP. The accreditation standards of the CAAM-HP mainly focus on five areas - institutional setting, medical students, educational programme, faculty and educational resources (13).

\section{Climate Change}

Climate change is predicted to increase extremes of climate in the Caribbean including an increase in seasonal dry periods, and of average temperatures (14). With warming temperatures, the oceans get warmer increasing the probability and strength of hurricanes. The recent major hurricanes Irma and Maria (September 2017) which devastated many Caribbean islands has affected the functioning of many medical schools.

\section{SIGNIFICANCE TO MEDICAL EDUCATORS ELSEWHERE}

Some features of OMS are unique while others will be of interest elsewhere. Climate change will have a global impact and teaching students about climate change can be an opportunity for educators (15). Social accountability will be an important issue and while the situation in OMS is unique in some respects, suggestions to address the issue would be of interest elsewhere. Changing ECFMG registration requirements can impact medical schools globally. Greater use of active learning strategies, small group learning and developing self-directed learning skills are global challenges. Faculty members in many locations face challenges in conducting research and publishing their findings.

In this article the authors have examined some of the challenges facing OMS. Table 1 summarises possible solutions for these shortcomings. Table 2 highlights lessons for educators working in schools located outside the Caribbean. Problems with quality of education, research and publication, faculty issues, problem with clinical education, changing accreditation requirements and climate change has been mentioned.

Table 2: Lessons to educators in other locations

\begin{tabular}{|c|c|}
\hline Challenge & Lesson learned \\
\hline Geographical and social isolation & $\begin{array}{l}\text { Creating linkages between educators in different schools and } \\
\text { locations. } \\
\text { Facilitating electronic communication forums. } \\
\text { Creating a faculty association(s). } \\
\text { Creating linkages with local educators from other disciplines. }\end{array}$ \\
\hline $\begin{array}{l}\text { Decreased opportunities for } \\
\text { development }\end{array}$ & $\begin{array}{l}\text { Webinars and online forums for educational development. } \\
\text { Regional fellowships and diplomas. } \\
\text { Continuing education programs. } \\
\text { Participation in programs conducted by regional medical associations } \\
\text { and accreditation agencies. } \\
\text { Conducting educational activities/programs at different OMS. } \\
\text { Schools support faculty members in their continuing education } \\
\text { efforts. }\end{array}$ \\
\hline $\begin{array}{l}\text { Less emphasis on practical skills } \\
\text { and small group learning }\end{array}$ & $\begin{array}{l}\text { Develop resources for small group learning and practical sessions. } \\
\text { Utilise computer and internet-based resources for facilitating these } \\
\text { sessions. } \\
\text { Develop linkages with faculty in other medical schools. } \\
\text { Clearly identify the learning sessions which will be conducted and } \\
\text { their objectives. }\end{array}$ \\
\hline
\end{tabular}


Table 2: (Continued)

\begin{tabular}{|c|c|}
\hline Challenge & Lesson learned \\
\hline $\begin{array}{l}\text { Greater emphasis on didactic } \\
\text { lectures }\end{array}$ & $\begin{array}{l}\text { Sessions for faculty on other learning modalities. } \\
\text { Strengthening the accreditation process. } \\
\text { Create resources for small group sessions. } \\
\text { Conduct sensitisation sessions for students. }\end{array}$ \\
\hline $\begin{array}{l}\text { Social accountability and } \\
\text { community-based learning }\end{array}$ & $\begin{array}{l}\text { Develop closer linkages with health systems of regions or countries } \\
\text { where the school is located. } \\
\text { Promote community-based learning especially in rural and } \\
\text { underserved areas. } \\
\text { Strengthen public health and community medicine departments. } \\
\text { Utilise community health facilities and general practitioners to provide } \\
\text { clinical exposure. } \\
\text { Involve the rural population in designing and monitoring student } \\
\text { learning environments. } \\
\text { Where possible use the internet to deliver lessons and learning } \\
\text { activities to students doing rotations in rural areas. }\end{array}$ \\
\hline $\begin{array}{l}\text { Decreased emphasis on research } \\
\text { and publication }\end{array}$ & $\begin{array}{l}\text { Develop linkages with regional and national research agencies. } \\
\text { Promote collaboration between institutions. } \\
\text { Reward faculty members who are engaging in research and } \\
\text { publication. } \\
\text { Accrediting agencies should emphasise research as a key component } \\
\text { of a medical school. } \\
\text { Allocate financial resources for research and publication. }\end{array}$ \\
\hline $\begin{array}{l}\text { Problems with clinical teaching } \\
\text { facilities }\end{array}$ & $\begin{array}{l}\text { Schools in other regions usually operate their own teaching hospitals } \\
\text { and/or use hospitals located in close proximity to the school. } \\
\text { Also most doctors in teaching hospitals are members of the faculty } \\
\text { hence these problems may be less or not relevant to other regions. }\end{array}$ \\
\hline $\begin{array}{l}\text { Changing accreditation } \\
\text { requirements }\end{array}$ & $\begin{array}{l}\text { Accreditation agencies can critically examine the WFME standards and } \\
\text { utilise an accreditation system in line with the standards. } \\
\text { These requirements can also impact health manpower migration and } \\
\text { may need discussion among various stakeholders. }\end{array}$ \\
\hline Climate change & $\begin{array}{l}\text { Medical schools along with other institutions and agencies can } \\
\text { conduct research on the impact of climate change. } \\
\text { Schools should educate students about the health impact of climate } \\
\text { change. } \\
\text { Faculty and students can be powerful advocates for strategies to } \\
\text { mitigate the effects of climate change. } \\
\text { Medical schools can become involved with civil society organisations } \\
\text { lobbying/working to reduce the impact of climate change. }\end{array}$ \\
\hline
\end{tabular}




\section{REFERENCES}

1. Eckhert LN. Perspective: private schools of the Caribbean: outsourcing medical education. Acad Med. 2010;85:622-30. https://doi.org/10.1097/ ACM.0b013e3181d2aee1.

2. Croasdale M. Quality concerns spur scrutiny of Caribbean medical schools. 2006 Jan. [cited 2017 Sept 20]. Available from: http:// www.ama-assn.org/amednews/2006/01/16/ prl10116.htm

3. Ceaser M. US exam boards urge scrutiny of offshore medical schools. Lancet. 2006;367:555. https://doi.org/10.1016/ S0140-6736(06)68202-0.

4. van Zanten M, Boulet JR. Medical education in the Caribbean: variability in medical school programs and performance of students. Acad Med. 2008;83(10 Suppl):S33-S36. https://doi.org/10.1097/ ACM.0b013e318183e649.

5. CAAM-HP. Caribbean accreditation authority for education in medicine and other health professions. Capacity building workshop [cited 2017 Sept 20]. Available from: http:/www.caam-hp.org/workshop. html

6. Kashaf S. Clinical skills in the age of Google: a call for reform and expansion of the USMLE step 2 CS. Acad Med. 2017;92:734. https://doi.org/10.1097/ ACM.0000000000001707.

7. Shankar PR. Challenges in implementing an integrated curriculum in a Caribbean medical school. Education in Medicine Journal. 2014;6(4):E74-7. https://doi. org/10.5959/eimj.v6i4.290.

8. Morgan J, Crooks VA, Sampson CJ, Snyder J. "Location is surprisingly a lot more important than you think": a critical thematic analysis of push and pull factor messaging used on Caribbean offshore medical school websites. BMC Med Educ. 2017;17:99. https://doi.org/10.1186/s12909017-0936-x.
9. Halperin EC, Goldberg RB. Offshore medical schools are buying clinical clerkships in U.S. hospitals: the problem and potential solutions. Acad Med. 2016;91:639-44. https://doi.org/10.1097/ ACM.0000000000001128.

10. Burdick WP, van Zanten M, Boulet JR. The shortage of clinical training sites in an era of global collaboration. Acad Med. 2016;91:615-7. https://doi.org/10.1097/ ACM.0000000000001129.

11. Beninger $P$, Salem DN, Boumil MM, Jotawni R. Medical schools' competition for clinical training sites. Acad Med. 2016;91:1588. https://doi.org/10.1097/ ACM.0000000000001428.

12. Educational Commission for Foreign Medical Graduates. Medical school accreditation requirement for ECFMG certification. 2017 May. [cited 2017 Sept 19]. Available from: http://www.ecfmg.org/ about/initiatives-accreditation-requirement. html.

13. Caribbean Accreditation Authority for education in medicine and other health professions. Standards for the accreditation of medical schools in the Caribbean community (CARICOM). Revised 2017. [cited 2017 Sep 21]. Available from: http:// www.caam-hp.org/documents.html

14. Cashman A, Nurse L, John C. Climate change in the Caribbean: the water management implications. The Journal of Environment and Development. 2010;19:42-67. https://doi. org/10.1177/1070496509347088.

15. Maxwell J, Blaski G. Teaching about climate change in medical education: an opportunity. J Public Health Res. 2016;5:673. https://doi. org/10.4081/jphr.2016.673. 
